\title{
A NEW THREAT LANDSCAPE IN 2015
}

\author{
Rohan Gunaratna ${ }^{1}$
}

International Centre for Political Violence and Terrorism

\begin{abstract}
:
The al Qaeda-centric terrorist landscape is eclipsed by an Islamic State (IS)-centric threat landscape. Today, an al Qaeda-IS hybrid influences and shapes the global threat landscape of political violence. With three dozen threat groups in Asia, Africa and the Middle East expressing support to the Caliphate and pledging allegiance to self-styled Caliph Abu Bakr al Baghdadi in 2014, IS will expand its international footprint in 2015. IS is transforming from a group in the Iraq and Syrian Theatre to a global network.
\end{abstract}

Keywords: Al Qaeda, Islamic State, terrorism, Syria, Iraq, new threats.

\section{Resumen:}

El paisaje terrorista de una organización centralizada como Al Qaeda se ve eclipsado por una amenaza central que es el Estado Islámico. Hoy en día la amalgama híbrida Al Qaeda - Estado Islámico configura la amenaza global de la violencia política. Con tres docenas de grupos en Asia, África y Oriente Medio declarando su apoyo al Califato y prometiendo lealtad al autodenominado Califato de Abu Bakr al Baghdadi en 2014, el Estado Islámico ampliará su presencia internacional en 2015. El Estado Islámico, de ser un grupo instalado en el teatro de Siria e Iraq, se está transformando en una red global.

Palabras clave: Al Qaeda, Estado Islámico, terrorismo, Siria, Iraq, nuevas amenazas.

Copyright @ C UNISCI, 2015.

Las opiniones expresadas en estos artículos son propias de sus autores, y no reflejan necesariamente la opinión de UNISCI. The views expressed in these articles are those of the authors, and do not necessarily reflect the views of UNISCI.

\footnotetext{
${ }^{1}$ Rohan Gunaratna is Head of International Centre for Political Violence and Terrorism Research of Rajaratnam School of International Studies, Nanyang Technological University.

E-mail: isrkgunaratna@ntu.edu.sg.
} 


\section{Introduction}

The galaxy of threat groups inspired and instigated by al Qaeda present a growing challenge to global harmony. Despite the presence of the world's finest standing armies in Afghanistan and Iraq, the insurgent, terrorist and extremist groups in the two most violent conflict zones survived. The unwillingness of Western and their Middle Eastern partners to deploy ground troops in Iraq, the pressure to pull out from Afghanistan, and the reluctance of more countries to join the fight perpetuate conflict. In a trajectory of growth, the ruthlessness and resilience of the violent actors threaten international security.

The international neglect of Iraq led to the rise of the Islamic State of Iraq and Syria (ISIS), an episode likely to repeat itself in Afghanistan in 2015-6. Although the international coalition formed in September 2004 in Iraq and Syria offer hope, a greater commitment of its constituents to fight on the ground is needed. Unless there is greater will on the part of the community of nations to fight violent actors and commitment of capabilities to counter their vicious ideologies, the global threat of violence and extremism will spread in 2015 .

\section{The Context}

Today, the most violent theaters of conflict are in the Middle East (Syria-Iraq, Yemen); Asia (Pakistan-Afghanistan), and Africa (Nigeria and Somalia). With less than 200 members, al Qaeda itself has become exceptionally weak but it's associates and affiliates have become strong. The most violent threat groups are the Islamic State (IS), The Taliban, al Qaeda in the Arabian Peninsula, Boko Haram and al Shabab. While these high profile groups will continue to pose a threat in 2015, several existing groups in the Middle East, Africa, and Asia are likely to grow stronger. They include al Nusra also known as al Qaeda in Syria, Turkistan Islamic Party in Western China, al Qaeda in the Indian Subcontinent. Although non-Muslim groups from Philippines to India and Peru to Colombia present a security threat, the ethno nationalist and left/right wing groups present a localized threat.

The epicenters of global terrorism today are in the Levant, where IS is the lead actor, and South Asia, where Taliban is the lead actor. In Africa, a new epicenter is likely to develop unless stability is restored in Libya, Egypt, especially in the Sinai, northern Mali/Southern Algeria, Somalia and Nigeria. At present, the threat in Africa's north is moving from Maghreb to the Sahel; in Africa's east, al Shabab in Somalia is disintegrating; and in Africa's west, Boko Haram in Nigeria is developing into a regional movement with cells in Niger, Chad and Cameroon.

Since June 2014, the spectacular military successes by the IS against the Iraqi and Syrian forces and continuing barbarism against Sunnis who resist them shock the world. The IS generated fear psychosis paralyzed Iraqi and Syrian forces from Mosul to Raqqa. While Iraqi and Syrian Sunni Muslims have suffered the most, the systematic killing, maiming and injury of Christians, Yazidis, Shia, Kurds and other faiths and communities by IS continues. The IS engages in the destruction of Islamic shrines and monuments, enslavement of women, beheading of regime elements and recruitment of children. IS is creating an environment of fear, suspicion and prejudice between communities that historically coexisted. Through IS propaganda projecting itself as followers of Islam and enforcers of Sharia, it seeks to justify its actions. IS activities find resonance among the radicalized, a narrow segment of Muslim communities vulnerable to recruitment. 


\section{Insurgent and Terrorist Capabilities}

The Western attempts to replace regimes and instill democracies in Iraq, Libya and now Syria ended in catastrophic failures. The interventions generated highly charged environments conducive for the spawning of terrorist and extremist groups. In Iraq, harnessing Iraqi and global Muslim sentiments, Abu Musab al Zarqawi, al Qaeda's emir for the Levant created al Qaeda in Iraq. Although he was killed, his Iraqi pupils sustained his vision of takfirism focusing on Sunni-Shia sectarianism. Furthermore, the Arab Spring created the conditions for a new series of groups to emerge exploiting the freedoms of assembly, protest, demonstration, and expression. After having fought the most advanced militaries, insurgents and terrorists outclassed the local Iraqi and Afghan forces.

IS strength is not only in the physical territories it controls but its expanding virtual presence. Since its declaration of a caliphate, IS mesmerized vulnerable Muslims and the support for IS is growing. IS brand appeals to a segment of both convert and cradle Muslims in North America, Europe, Balkans, Africa, Middle East, Caucasus, Asia and Australia. Those self-radicalized individuals either travel to the Middle East to join IS or operate from their home soil. Although most governments and public perceive IS as a regional threat, it is not. Presenting a threat beyond Iraq, Syria and Lebanon, IS intend to expand and create a global caliphate. Like al Qaeda, IS is building a global constituency to advance its global ambitions.

IS mastery of social media has created a support network especially among the youth and teenagers. The Internet savvy $\mathrm{X}, \mathrm{Y}$, and $\mathrm{Z}$ generations are vulnerable to IS messaging especially its images and videos. To spread its ideological virus, IS exploit and its supporters harness You-tube, Facebook, and Twitter. Unlike al Qaeda's boring ranting on the West attacking Muslims and Islam, IS high definition Hollywood quality action packed thrillers lure potential supporters and sympathizes. Governments and their partners fighting IS are still planning to fight IS information order of battle. Like al Qaeda was dismantled in Afghanistan in late 2001, even if IS structures are degraded, the idea of establishing a Caliphate through violence will linger in cyber space.

\section{Recent and Likely Developments}

The 30,000 Shia and Sunni foreign fighters in the Syrian, Iraqi and Lebanon theaters not only threaten the Levant but their countries of origin. Like the Afghan Veterans formed the nuclei of the current wave of violence, the Iraqi, Syrian and Lebanese returnees possess the experience and expertise to create and resource threat groups. They travel home with motivation, skills and a network to spread their ideology and conduct attacks. With a fledgling external wing, IS is likely to target countries participating in the international coalition. The inspired, instigated and directed attacks are likely to occur both in third countries and on the soil of participating countries. As evident in Belgium (May), Canada (October), and Australia (December) in 2014, IS is likely to inspire more attacks against government and civilian targets in 2015 .

Among the other conflict arenas attracting foreign fighters are Yemen, Somalia, and tribal Pakistan. The most active Asian threat groups, the Afghan and Pakistani Taliban, threaten to recapture Afghanistan. After relocation to Afghanistan, the Pakistani Taliban in particular seek to attack Pakistan. In a state of active conflict, the Pakistani Taliban present a much greater threat to Pakistan than to Afghanistan. Similar to IS forerunners al Nusra and ISIS in Western Iraq captured eastern and northern Syria, the two Taliban entities have already established a presence in southern and eastern Afghanistan. The attacks including the suicide attacks targeting Kabul, the capital, are likely to gather momentum. Pakistani Taliban 
in tribal Pakistan and Afghan Taliban in mainland and tribal Pakistan aims to create Taliban style Islamic states in Afghanistan and Pakistan.

Although the media attention is focusing on Iraq and Syria, the developments in Pakistan and Afghanistan are threatening their neighbors. Threat groups from the Af-Pak theatre seek to infiltrate Central, South, Southeast and Northeast Asia. Like the Iraqisation of al Qaeda in Iraq produced ISI, the Asianization of al Qaeda has produced al Qaeda in the Indian Subcontinent (AQIS), threatening South Asia and Myanmar. After a hiatus of a decade, al Qaeda returned as AQIS. While al Qaeda was predominantly Arab, AQIS is staffed by Pakistani but includes Indian, Maldivian, Bangladeshi and Myanmar (Rohingiya) Muslims. AQIS is seeking to build a network in South Asia and Arakan region of Myanmar. In Southeast Asia, where over 200 recruits travelled to Syria and Iraq, 16 terrorist and extremist groups have expressed support for IS. The foreign fighter recruits include both Central Asians and Uighurs from Northeast Asia. Increasingly, they travel with their families.

\section{Confronting IS}

The belief that insurgent and terrorist groups can be defeated by an air campaign is flawed. Without ground troops no insurgent or terrorist campaign can be defeated. As evident in Iraq and Syria, and tribal Pakistan, air power can weaken but not eliminate a group. Air power will also lead to civilian fatalities and casualties bolstering support for insurgents and terrorists.

Ideologically and methodologically, IS and al Qaeda are compatible. The al Qaeda leader Ayman al Zawahiri and IS leader Abu Bakr al Baghdadi are at conflict with each other. Their rivalry turned village against village, friend against friend, family against family. If either of these leaders die or are killed, the two most powerful threat groupings are likely to merge posing a high order threat to global security.

The targeting strategy should be multi pronged, multi agency, multi national, and multi jurisdictional. What is needed is a bottom up strategy of attrition of fighters, destruction of their assets especially logistics and supplies, and simultaneously impeding their capacity to replenish human losses and material wastage. In parallel with targeting the middle level leadership, experts and membership, it is paramount to engage supporters and weaken the support base. In Iraq, for instance, political and economic initiatives to wean away Sunni support and sympathy is essential.

As a third of the IS fighters are foreign, governments worldwide should criminalize advocacy, support and participation in foreign conflicts. As a fourth of the fighters who travel are disillusioned with IS, security and intelligence services directly and indirectly should reach out to those with second thoughts. The key is for governments to work with community partners, religious institutions, educational institutions and the media to create an anti-IS environment.

\section{Conclusion}

With terrorist groups developing hyper mobile insurgent capabilities and invasion of the social media, the frontlines of terrorism has changed. Al Qaeda's most virulent strain, the IS, presents a threat to humanity and an existential threat to the nation-states of the Levant. In the immediate (1-2 years) and a mid-term (5 year), the threat to the stability of Middle East and North Africa will grow. The tempo of attack and the graphic killings is creating momentum 
for other groups and home grown terrorists to attack. It is likely that the bloody attack on the school in Peshawar in December 2014 by Pakistani Taliban was an attempt to rival IS mass murders.

Despite an international coalition, IS occupy swaths of territory in Iraq, Syria, and Lebanon. The hyper mobile warfare capability of IS resembles more of a semi conventional army rather than an insurgent - terrorist entity. Having infiltrated its neighborhood and beyond, IS threaten the stability and security of the Kingdoms of Jordan, Saudi Arabia and the Gulf states. Although IS has not yet attacked Iran and Israel, they are its avowed targets. In addition to IS, its splinter Jabat al Nusra (al Nusra) presents a long term threat to Iran, Israel, and Turkey, three powerful states. With its extraordinary wealth and media appeal, IS will spur revolts in Sunni states from Egypt to Libya and Tunisia.

What sustains the IS threat is global and regional geopolitical and geostrategic rivalry. Considering IS anti-Iran and anti-Shia orientation, Iran has demonstrated its commitment. In addition to collaborating with the Iraqi and Syrian regimes, Iranian special units, Shia militia and Hezbollah are at the forefront of fighting IS. In the larger interest of restoring peace and security, the Obama Administration has the potential to unite the major international and Sunni Muslim players. The key is to bring in Russia and Turkey to join the the IS fight. As rising superpowers, India and China should commit to restoring stability. Otherwise, it is a question of time before the specter of terrorism will haunt those countries that lack the vision and political will to join in the fight. Unless IS is contained and isolated, IS will most likely replace al Qaeda as the leader of the global movement of Muslim insurgent, terrorist and extremist groups in 2015. By mobilizing broad based international support, a counter insurgent and a counter terrorist environment can be created. Terrorism and its precursor extremism will remain the tier one national security threat to most countries in 2015. 